\title{
Effect of metals on the lytic cycle of the Coccolithovirus, EhV86
}

\section{Martha Gledhill ${ }^{1}{ }^{*}$, Aurélie Devez ${ }^{1+}{ }^{1}$ Andrea Highfield ${ }^{2}$, Chloe Singleton $^{2}$, Eric P. Achterberg ${ }^{1}$ and Declan Schroeder ${ }^{2} *$}

${ }^{1}$ School of Ocean and Earth Science, University of Southampton, National Oceanography Centre, Southampton, UK

${ }^{2}$ Marine Biological Association of the UK, Citadel Hill, Plymouth, UK

\section{Edited by:}

Christel Hassler, University of Technology Sydney, Australia

Reviewed by:

Rachel Narehood Austin, Bates College, USA

Peter Croot, National University of Ireland - Galway, Ireland

*Correspondence:

Martha Gledhill, Ocean and Earth

Science, National Oceanography

Centre - Southampton, University of

Southampton, Southampton, SO14

3ZH, UK.

e-mail:martha@soton.ac.uk;

Declan Schroeder, Marine Biological

Association of the UK, Citadel Hill,

Plymouth, PL1 2PB, UK.

e-mail:dsch@mba.ac.uk

\section{${ }^{\dagger}$ Present address:}

Aurélie Devez, IFREMER, Centre de

Brest, Department

ODE/DYNECO/PELAGOS, Pointe du

Diable, BP 70, 29280 Plouzané,

France
In this study we show that metals, and in particular copper (Cu), can disrupt the lytic cycle in the Emiliania huxleyi - EhV86 host-virus system. E. huxleyi lysis rates were reduced at high total $\mathrm{Cu}$ concentrations (> approximately $500 \mathrm{nM}$ ) in the presence and absence of EDTA (ethylenediaminetetraacetic acid) in acute short term exposure experiments. Zinc $(\mathrm{Zn})$, cadmium (Cd), and cobalt (Co) were not observed to affect the lysis rate of EhV86 in these experiments. The cellular glutathione (GSH) content increased in virus infected cells, but not as a result of metal exposure. In contrast, the cellular content of phytochelatins (PCs) increased only in response to metal exposure. The increase in glutathione content is consistent with increases in the production of reactive oxygen species (ROS) on viral lysis, while increases in PC content are likely linked to metal homeostasis and indicate that metal toxicity to the host was not affected by viral infection. We propose that Cu prevents lytic production of EhV86 by interfering with virus DNA (deoxyribonucleic acid) synthesis through a transcriptional block, which ultimately suppresses the formation of ROS.

Keywords: copper, Emiliania huxleyi, phytoplankton, virus, cadmium, phytochelatins, thiols, glutathione

\section{INTRODUCTION}

Viruses have been shown to be the most ubiquitous biological entities detected in the ocean to date (Bergh et al., 1989; Sandaa, 2008), with over a quarter of organic carbon in the sea passing through the "viral shunt" (Wilhelm and Suttle, 1999). Viruses not only directly affect the abundance and diversity of the organisms they infect (e.g., Sorensen et al., 2009), but viral lyses results in the release of nutrients and organic carbon and thus influences the biogeochemical cycles of key elements such as carbon, nitrogen, and iron (Fe; Gobler et al., 1997; Mioni et al., 2005; Weinbauer et al., 2009). Therefore viruses are important players in global ecosystems (Suttle, 2007). The relationship between virus and host in the marine environment is thought to be complex, however the Emiliania huxleyi - EhV host-virus system has emerged as one of the best model systems to investigate algal host-virus interactions (Bidle and Vardi, 2011).

EhV86, a Coccolithovirus, is responsible for the termination of naturally occurring blooms of the coccolithophore E. huxleyi (Schroeder et al., 2002; Wilson et al., 2002). More recently, studies into the mechanisms of EhV86 infection have revealed an animallike infection strategy (Mackinder et al., 2009), exploiting pathways previously thought to be restricted to higher multicellular organisms. These pathways include the synthesis of ceramide (Wilson et al., 2005; Han et al., 2006) inducing programmed cell death
(PCD) in the unicellular coccolithophore (Bidle and Falkowski, 2004; Pagarete et al., 2009; Vardi et al., 2009). Notably, viral lysis of E. huxleyi by EhV86 also triggers the production of reactive oxygen species (ROS; Evans et al., 2006), which in turn induces caspase activity and consequently PCD (Bidle et al., 2007).

Cellular processes in micro-organisms are also strongly influenced by the chemistry of trace metals, which in turn influence the primary production and community structure in the ocean (Sunda, 1988; Morel and Price, 2003). Copper (Cu) and cadmium (Cd) are two trace metals that can be found at elevated levels in coastal environments (e.g., Braungardt et al., 2007). Copper is an essential cofactor of enzymes involved in a variety of physiological processes including respiration, photosynthesis, oxygen transport, and antioxidant defense. Therefore, $\mathrm{Cu}$ is required for growth by marine phytoplankton, but is toxic at elevated concentrations (Morel et al., 1978; Brand et al., 1986; Gledhill et al., 1997). Copper predominantly occurs as $\mathrm{Cu}(\mathrm{II})$ but biological systems utilize the ability of $\mathrm{Cu}$ to undergo a redox cycle. It is this property that gives $\mathrm{Cu}$ its toxic potential. Copper catalyzes the reaction between superoxide and hydrogen peroxide, producing the highly reactive hydroxyl radical via the following cycle:

$$
\begin{aligned}
& \mathrm{Cu}^{2+}+\mathrm{O}_{2}^{\bullet-} \rightarrow \mathrm{Cu}^{+}+\mathrm{O}_{2} \\
& \mathrm{Cu}^{+}+\mathrm{H}_{2} \mathrm{O}_{2} \rightarrow \mathrm{Cu}^{2+}+\mathrm{OH}^{\bullet-}+\mathrm{OH}^{-}
\end{aligned}
$$


The reaction with hydrogen peroxide will compete with the faster reaction between $\mathrm{Cu}^{+}$and $\mathrm{O}_{2}^{\bullet-}$ (Voelker et al., 2000; Heller and Croot, 2010, 2011):

$\mathrm{Cu}^{+}+\mathrm{O}_{2}^{\bullet-} \rightarrow \mathrm{Cu}^{2+}+\mathrm{H}_{2} \mathrm{O}_{2}$

so that the production of the hydroxide radical will be influenced by the ambient redox environment (which is reducing within cells; Schafer and Buettner, 2001) and the relative concentrations of $\mathrm{Cu}$ and superoxide.

Hydroxyl radicals can cause oxidative damage to cellular components such as deoxyribonucleic acid (DNA), proteins, and lipids. For example, $\mathrm{Cu}$ causes damage to DNA by binding near guanine bases, where it is reduced to $\mathrm{Cu}(\mathrm{I})$ and then reoxidized to $\mathrm{Cu}(\mathrm{II})$ by reaction with hydrogen peroxide producing hydroxyl radicals. The radicals then mediate DNA strand breakage in close proximity to the bound $\mathrm{Cu}$ (Sagripanti and Kraemer, 1989; Aruoma et al., 1991). The redox properties of $\mathrm{Cu}$ also allow the metal to bind to several types of amino acid residues and therefore $\mathrm{Cu}$ could be inappropriately incorporated into proteins and enzymes that normally bind other metal ions. This results in a loss of function through inactivation or changes in conformational fold. In humans for example, $\mathrm{Cu}$ may contribute to the development of Alzheimer's disease, along with $\mathrm{Fe}$ and zinc $(\mathrm{Zn})$, as it has been found to induce aggregation of the $\beta$-amyloid $(A \beta)$ protein and has been found in high quantities $(0.44 \mathrm{mM})$ in Alzheimer plaques (Lovell et al., 1998; Curtain et al., 2001). Moreover, these high $\mathrm{Cu}$ levels are linked to an increase in oxidative stress which plays a central role in neurodegenerative disorders (Permyakov, 2009).

Copper has long been known to possess antimicrobial and antiviral properties, and in the last decade studies have suggested that $\mathrm{Cu}$ surfaces could be reintroduced into hospitals to reduce the transmission of microbes such as methicillin resistant Staphylococcus aureus (Noyce et al., 2006a), Escherichia coli O157 (Noyce et al., 2006b), and influenza A virus (Noyce et al., 2007). The mechanisms of $\mathrm{Cu}$ disruption of virus infection may vary depending on the virus and have yet to be fully understood (Karlstrom and Levine, 1991a,b; Sagripanti et al., 1997; Horie et al., 2008), however there is some evidence to suggest that inactivation of viruses can proceed via $\mathrm{Cu}$ mediated DNA damage as described above (Levinson et al., 1973; Sagripanti et al., 1997).

Cadmium $(\mathrm{Cd})$ had been considered a non-essential metal, but more recently a unique biological role for $\mathrm{Cd}$ has been identified in marine diatoms. It has been shown that $\mathrm{Cd}$ can replace $\mathrm{Zn}$ as a metal of the Zn carbonic anhydrase (Price and Morel, 1990), and that $\mathrm{Cd}$ carbonic anhydrases can play a role in the acquisition of inorganic carbon for photosynthesis in the oceans (Lane et al., 2005). High levels of anthropogenic Cd in the coastal environment has also led to toxicological effects in exposed marine organisms. For example, $\mathrm{Cd}$ is reported to reduce reproduction rates in phytoplankton (Brand et al., 1986). The mechanism of Cd toxicity is known in animal systems where Cd complexes glutathione (GSH) and protein-bound sulfhydryl groups, resulting in enhanced production of ROS such as superoxide ion, hydroxyl radicals, and hydrogen peroxide (Stohs et al., 2001). Cadmium has been shown to inhibit the enzymatic activity of the $\mathrm{Cu} / \mathrm{Zn}$-superoxide dismutase (Cu/Zn-SOD) from rat liver (Hussain et al., 1987) and human
$\mathrm{Cu} / \mathrm{Zn}-\mathrm{SOD}$ (Huang et al., 2006). This occurs through replacement of the normally bound $\mathrm{Zn}$ (II) ion with a $\mathrm{Cd}(\mathrm{II})$ ion at the active site.

Elevated $\mathrm{Cu}$ and $\mathrm{Cd}$ concentrations in many marine eukaryotic phytoplankton are tolerated through the induction of phytochelatins, thiols of the general formula ( $\gamma$-Glu-Cys $)_{n}$-Gly, where $n$ commonly ranges between 2 and 4 (Ahner and Morel, 1995; Ahner et al., 1995; Kawakami et al., 2006b,c; Devez et al., 2009). Phytochelatins and other thiols may also be released into the surrounding media, reducing free metal concentrations, and potentially affecting metal bioavailability (Lee et al., 1996; Leal et al., 1999; Vasconcelos and Leal, 2001; Vasconcelos et al., 2002). Phytochelatins are synthesized from GSH, which is also known to respond to oxidative stress. However, while the intracellular abundance of PCs is thought to be linked to metal concentrations in the surrounding water (e.g., Ahner and Morel, 1995; Ahner et al., 1995; Morelli and Scarano, 2001; Dupont and Ahner, 2005; Le Faucheur et al., 2005; Kawakami et al., 2006b; Pawlik-Skowronska et al., 2007; Morelli and Fantozzi, 2008; Devez et al., 2009), cellular GSH abundance, and metal concentrations are not necessarily directly related (Kawakami et al., 2006c; Scheidegger et al., 2011). Glutathione has many metabolic roles (Mendoza-Cozatl et al., 2005), however, exogenous GSH is known to affect replication of Herpes simplex virus type 1 (HSV-1) by interfering with the very late stages of the virus life cycle, without otherwise affecting host cellular metabolism (Palamara et al., 1995).

Metals thus have the potential to impact host-virus interactions. However, to our knowledge, the effects of metals have not yet been assessed for any marine host-virus system. The aim of this study was therefore to undertake a preliminary investigation into interactions between trace metals and the E. huxleyi - EhV86 system. We subsequently examined (1) the impact of elevated $\mathrm{Cu}$ and Cd concentrations on the EhV86 lytic cycle and (2) the cellular mechanism involved in these interactions.

\section{MATERIALS AND METHODS}

Sterile trace metal clean techniques were used for culturing. Glassware and polycarbonate bottles (Nalgene) were acid washed (1 M $\mathrm{HCl}$ ) for at least $24 \mathrm{~h}$ prior to use, $4 \mathrm{~L}$ polycarbonate culture vessels (Nalgene) were double bagged (Nalgene autoclavable plastic bags) prior to autoclaving at $120^{\circ} \mathrm{C}$ for $30 \mathrm{~min}$.

\section{CULTURE CONDITIONS}

Emiliania huxleyi (strain CCMP 1516) was obtained from the Provasoli-Guillard Center for Culture of Marine Phytoplankton (CCMP). Experiments reported here focused on acute short term (4 days) effects. E. huxleyi was batch cultured in $\mathrm{f} / 2$ minus Si medium prepared using $0.2 \mu \mathrm{m}$ filtered seawater collected from the North Atlantic Gyre in the Canary Basin (between 24.1 and $29.5^{\circ} \mathrm{N}$ and 23.4 and $27.6^{\circ} \mathrm{W}$ ). The culture medium ( $\mathrm{pH}=7.8 \pm 0.1)$ was allowed to equilibrate overnight and then filtered sterilized $(0.2 \mu \mathrm{m}$, Sartorius) prior to seeding with E. huxleyi. Although it was possible that viruses already present in the seawater would have passed through the $0.2-\mu \mathrm{m}$ filter, in practice we did not observed any evidence of lysis of E. huxleyi in our control cultures, indicating that this was not a problem in these experiments. Concentrations of the nutrients nitrate $\left(\mathrm{NaNO}_{3}\right)$ and phosphate 
$\left(\mathrm{NaH}_{2} \mathrm{PO}_{4}\right)$ added to the seawater were $3 \times 10^{-4}$ and $1 \times 10^{-5} \mathrm{M}$, respectively. Concentrations of trace metals added to the seawater were $10 \mathrm{nM} \mathrm{Cu}, 100 \mathrm{nM}$ molybdenum, $4 \mathrm{nM} \mathrm{Zn}, 2.5 \mathrm{nM}$ cobalt (Co), $23 \mathrm{nM}$ manganese, $450 \mathrm{nM}$ Fe, and $10 \mathrm{nM}$ selenium. Media used for initial experiments with $2.5 \mu \mathrm{M}$ added Cd, Co, $\mathrm{Cu}$, and $\mathrm{Zn}$ were carried out in the presence of $5 \mu \mathrm{M}$ ethylenediaminetetraacetic acid (EDTA). Experiments with different $\mathrm{Cu}$ concentrations were carried out in the presence and absence of $5 \mu \mathrm{M}$ EDTA, and experiments investigating thiol production and RNA expression were carried out in the absence of EDTA. Cultures were maintained at $15 \pm 1{ }^{\circ} \mathrm{C}$ under a light/dark cycle of $12: 12 \mathrm{~h}$ and at an illumination of $150 \mu \mathrm{mol}$ photons $\mathrm{m}^{-2} \mathrm{~s}^{-1}$ in a growth cabinet (MLR-350, Sanyo).

\section{VIRUS CULTURE MAINTENANCE}

The Coccolithovirus EhV86 was propagated by using acclimated and synchronized batch cultures of E. huxleyi 1516 grown in $\mathrm{f} / 2$ medium without EDTA and Si (Schroeder et al., 2002). The occurrence of lysis was generally indicated by a change in the culture appearance, from a green to a chalky white color. The new virus stock solution was obtained from an E. huxleyi culture grown to a cell density of approximately $1 \times 10^{6}$ cells $\mathrm{mL}^{-1}$ at a multiplicity of infection of approximately 10 . The new virus stock solution was labeled and stored in the dark at $4^{\circ} \mathrm{C}$ until required.

\section{METAL AND VIRUS ADDITION}

The virus and the single studied metal $(\mathrm{Cd}, \mathrm{Co}, \mathrm{Cu}, \mathrm{Zn})$ were added simultaneously. The addition of EhV86 virus, in excess for infection, was done to exponentially growing E. huxleyi host cultures approximately 4 days after subculturing. In initial experiments investigating effects of $\mathrm{Cd}, \mathrm{Co}, \mathrm{Cu}$, and $\mathrm{Zn}$, metals were added at a concentration of $2.5 \mu \mathrm{M}$ in excess of concentrations already present in the media. A second experiment investigated a range of $\mathrm{Cu}$ concentrations between $125 \mathrm{nM}$ and $1 \mu \mathrm{M}$. For the final experiment investigating the mechanism of the $\mathrm{Cu}$ virus interaction, $\mathrm{Cu}$ was added at a total concentration of $1.25 \mu \mathrm{M}$ and $\mathrm{Cd}$ at 5.0 $\mu \mathrm{M}$. Non-infected cultures with and without metal were used as a control in parallel for each virus/metal treatment.

Growth of the cultures was monitored daily by enumerating cells (Multisizer ${ }^{\mathrm{TM}}$ II coulter counter). Cell numbers were used to guide subsequent sampling frequency for PCs and viral ribonucleic acid (RNA). Cultures were sampled daily for virus counts and on alternate days for thiol content. RNA expression was sampled on days 5,7 , and 10 post infection for $\mathrm{Cu}$ and daily up to day 8 post infection for Cd. All analyses were carried out in duplicate. For virus counts, $1 \mathrm{~mL}$ was sampled and fixed using $50 \mu \mathrm{L}$ of polyoxymethylene (paraformaldehyde, Sigma Aldrich, 1\% final concentration) and subsequently stored at $-80^{\circ} \mathrm{C}$ for later analysis by flow cytometry. For thiol analysis, $500 \mathrm{~mL}$ of culture solution was filtered $(0.45 \mu \mathrm{m}$ pore size nitrocellulose membrane filters, Whatman) under gentle vacuum pressure and stored at $-80^{\circ} \mathrm{C}$. For isolation of RNA, E. huxleyi cells were harvested via centrifugation and RNA was extracted from the pellets using the RNeasy Mini Kit (Qiagen) according to the manufacturer's instructions. Total RNA was DNase treated (Promega) to remove any DNA contamination and then quantified using the NanoDrop 1000 spectrophotometer (Thermo Scientific).
Cell counts from the coulter counter were used to calculate the average growth $(\mu)$ rates for E. huxleyi over the period of viral infection from the slope of a graph of $\ln$ (cells) against time. The viral lysis rate is then calculated from

$\mu_{+ \text {virus }}=\mu-\gamma_{\text {lysis }}$

where $\gamma_{\text {lysis }}$ is the E. huxleyi lysis rate, $\mu$ is the growth rate of E. huxley $i$ in control cultures or treatments containing the added metal, and $\mu_{+ \text {virus }}$ is the growth rate of E. huxleyi in infected cultures or infected cultures containing the added metal.

\section{FLOW CYTOMETRY}

Determination of the abundance of viral particles and E. huxleyi cells was performed simultaneously (FACSort, Becton Dickinson Biosciences). EhV86 were discriminated based on their green fluorescence and side scatter. E. huxleyi cells were counted based on their red and orange fluorescence signatures upon staining with SYBR Green I DNA dye (Schroeder et al., 2002; Wilson et al., 2002).

Comparison of fresh (coulter counter) and fixed (Flow Cytometry) E. huxleyi cell counts showed that a good agreement was observed between these two counting approaches ( $t$ test, $p>0.05$, $n=48)$.

\section{DETERMINATION OF PARTICULATE THIOLS}

The total concentrations of glutathione (GSH) and phytochelatins (PCs) in metal and virus exposed E. huxleyi cultures were determined according to the method reported by Kawakami et al. (2006a). Intracellular thiol measurements were performed in duplicate by reverse-phase high performance liquid chromatography (HPLC) with fluorescence detection.

Thiols were extracted on ice $(5 \mathrm{~min})$, following addition of $1.2 \mathrm{~mL}$ solution of $0.1 \mathrm{M} \mathrm{HCl}$ containing $5 \mathrm{mM}$ diethylenetriamine pentaacetic acid (DTPA, Fluka Biochemica) to a 2-mL microcentrifuge tube (Fisher) containing the filter with E. huxleyi biomass. The extract was centrifuged $\left(13000 \mathrm{~g} / 20 \mathrm{~min}\right.$ at $\left.4^{\circ} \mathrm{C}\right)$ and syringe filtered $(0.2 \mu \mathrm{m}$ pore size cellulose membrane, Minisart RC4, Sartorius) prior to reduction $(25 \mu \mathrm{L}$ of a 20 -mM 2-carboxyethylphosphine hydrochloride, 5 min, TCEP, Sigma). Further oxidation was minimized ( $5 \mathrm{mM}$ DTPA) and the extract was buffered at $\mathrm{pH}$ 8.2 (200 mM N-2-hydroxyethylpiperazine- $\mathrm{N}^{\prime}$-2-ethanesulphonic acid, HEPES). After a further $5 \mathrm{~min}, 10 \mu \mathrm{L}$ of a $100-\mathrm{mM}$ of a sulfurspecific fluorescent tag monobromobimane was added $(\mathrm{MBrB}$ in acetonitrile, Fisher) followed by $465 \mu \mathrm{L}$ of the HEPES/DTPA pH 8.2 solution. The derivatization procedure was carried out in a dark room under dim red light conditions. After $15 \mathrm{~min}$, the reaction was stabilized and the derivatization of thiols by $\mathrm{MBrB}$, stopped by addition of $100 \mu \mathrm{L}$ of $1 \mathrm{M}$ methanesulfonic acid (99\%, Sigma). Vials were stored in the dark at $4^{\circ} \mathrm{C}$ until HPLC analysis.

Thiols were analyzed by reverse-phase HPLC with fluorescence detection (Kawakami et al., 2006a). The HPLC comprised a system controller (Shimadzu SCL-10A) and two pumps (Shimadzu LC-10ADvp), an autosampler (Shimadzu SIL-10ADVP) and a fluorescence detector (Shimadzu RF-10A XL) operating at $380 \mathrm{~nm}$ (excitation) and $470 \mathrm{~nm}$ (emission) wavelengths. Separation of the thiols was carried out using a $150 \mathrm{~mm} \times 2.1 \mathrm{~mm}$ C-18 HPLC column (Ascentis, Supelco) with a $3-\mu \mathrm{m}$ particle size and a gradient program of $0-5 \mathrm{~min}, 10 \% \mathrm{~B}$; 5-18 $\mathrm{min}, 10-22 \% \mathrm{~B}$; $18-40 \mathrm{~min}$, 
$22-35 \% \mathrm{~B}$; 40-50 min, 35-100\%; 50-55 min, isocratic $100 \% \mathrm{~B}$; $55-58 \mathrm{~min}, 100-10 \% \mathrm{~B}$; $58-60 \mathrm{~min} 10 \% \mathrm{~B}$, where A was $0.1 \%$ trifluoroacetic acid (TFA, Fluka) and B was acetonitrile. The flow rate was $0.2 \mathrm{~mL} \mathrm{~min}^{-1}$.

Phytochelatin concentrations were standardized with GSH (reduced form, purity 99\%, Sigma) assuming that the fluorescence response was directly proportional to the number of thiol groups (Kawakami et al., 2006a). We used PCs directly produced by Phaeodactylum tricornutum under metal stress for identification of retention times for $\mathrm{PC}_{2}, \mathrm{PC}_{3}$, and $\mathrm{PC}_{4}$. GSH eluted at $11.4 \mathrm{~min}$ and PC2, 3, and 4 at 18.8, 21.7, and $24.2 \mathrm{~min}$, respectively. Cellular GSH and PC concentrations were normalized to the number of cells and are thus expressed in amol SH cell ${ }^{-1}$. The limit of detection, calculated from three times SD of a 5-pmol GSH standard, was $0.1 \mathrm{pmol}$ with a $100-\mu \mathrm{L}$ injection volume. Analytical variability within standards and samples was less than $10 \%$. The recovery of GSH added to samples prior to derivatization was determined to be $86 \pm 29 \%(n=11)$.

\section{ONE-STEP REVERSE TRANSCRIPTION-PCR}

RT-PCR detection of virus-related gene expression was undertaken using primers designed to amplify four viral genes, DNA polymerase (DNA pol), Helicase, proliferating cell nuclear antigen (PCNA) protein, and major capsid protein (MCP; Table 1). One-step RT-PCR was used to amplify $10 \mathrm{ng}$ RNA in $25 \mu \mathrm{L}$ reactions containing $1 \times$ One-step sensimix QPCR mix (with SYBR green), $7.5 \mathrm{pmol}$ forward primer, $7.5 \mathrm{pmol}$ reverse primer, and 5 units RNase inhibitor. Reactions were carried out in a Rotorgene 6000 QPCR machine (Corbett Research) using the following conditions: reverse transcription at $49^{\circ} \mathrm{C}$ for $10 \mathrm{~min}$, polymerase activation at $95^{\circ} \mathrm{C}$ for $10 \mathrm{~min}$, followed by 40 cycles of $95^{\circ} \mathrm{C}$ for $15 \mathrm{~s}$, $54^{\circ} \mathrm{C}$ for $15 \mathrm{~s}\left(60^{\circ} \mathrm{C}\right.$ for $\left.\mathrm{MCP}\right)$, and $72^{\circ} \mathrm{C}$ for $15 \mathrm{~s}$. Fluorescence was acquired at the end of each extension step on the green channel. RT-PCR reactions were subjected to melt curve analysis to ensure a single product had been generated by gradual melting from 72 to $95^{\circ} \mathrm{C}$ and fluorescence acquisition at each $1^{\circ} \mathrm{C}$ increment. RTPCR products were verified by gel electrophoresis on a $2 \%(\mathrm{w} / \mathrm{v})$ agarose gel in $1 \times$ TAE buffer and viewed on a UV transilluminator (Syngene).

\section{STATISTICAL ANALYSIS}

As analysis was only performed in duplicate, estimates of errors in growth, and lysis rates were calculated from the square route of the sum of squares of the SEs of the slopes of $\ln$ (cells) against time. The lack of experimental replication meant that the statistical significance of our results could not be tested and comparisons between treatments are thus qualitative.

\section{RESULTS}

\section{E. HUXLEYI - EhV86 INFECTION DYNAMICS IN THE PRESENCE OF VARIOUS METAL IONS}

Preliminary experiments, carried out with a range of metals $(\mathrm{Cu}$, Zn, Co, and Cd) on the E. huxleyi - EhV86 host-virus system indicated that viral lysis of E. huxleyi cells was disrupted in the presence of $\mathrm{Cu}$, but was similar to controls for the metals $\mathrm{Cd}$, Co, and $\mathrm{Zn}$ (Figure 1A). In this study we have interpreted our data qualitatively as lack of sufficient replicates in our experimental design precludes more quantitative estimates of the statistical significance of our results. However, $\mathrm{Cu}$ was consistently observed to disrupt viral lysis of E. huxleyi in all the experiments undertaken as part of this study. Furthermore varying the concentration of $\mathrm{Cu}$ in the absence and presence of EDTA indicated that viral lysis rates decreased with increasing $\mathrm{Cu}$ concentration and were lowest in the absence of EDTA (Figure 1D). Copper is known to be toxic to marine algae at high concentrations (e.g., Sunda and Guillard, 1976; Brand et al., 1986; Gledhill et al., 1997; Levy et al., 2007, 2008; Debelius et al., 2009), and indeed the growth rate of $E$. huxleyi was reduced at the highest $\mathrm{Cu}$ concentration when compared to control cultures (Figures 1A,C). However the cumulative effect of metal plus virus on host growth was only observed in $\mathrm{Cu}$ treatments and thus appeared to be a specific effect of $\mathrm{Cu}$. Further short term exposure experiments aimed at understanding the interaction between $\mathrm{Cu}$ and the E. huxleyi virus-host system focused on $\mathrm{Cd}$ and $\mathrm{Cu}$ as these two metals are both known to be toxic and they exhibited contrasting behaviors in our preliminary experiments. Furthermore EDTA was omitted in order to maximize the effect of trace metals on both host and virus.

PRODUCTION OF GLUTATHIONE AND PHYTOCHELATINS BY E. HUXLEYI The intracellular content of GSH and PCs in infected and noninfected E. huxleyi cells were determined in order to investigate oxidative stress and trace metal homeostasis during the course of the experiments. Post virus and metal addition growth curves for E. huxleyi in the thiol expression experiments are presented in Figure 2. Initial cell numbers were different for each experiment when virus and metals were added $\left(4.0 \pm 0.6 \times 10^{5}\right.$ cells $\mathrm{mL}^{-1}$ for the $\mathrm{Cu}$ experiment and $1.4 \pm 0.2 \times 10^{5}$ cells $\mathrm{mL}^{-1}$ for the $\mathrm{Cd}$ experiment), however, calculated growth rates were similar for

Table 1 | Primers used in this study.

\begin{tabular}{|c|c|c|c|c|}
\hline Primer name & Target (CDS) & Sequence $\left(5^{\prime}-3^{\prime}\right)$ & Amplicon size (bp) & Reference \\
\hline EhVpol_F & \multirow[t]{2}{*}{ DNA polymerase (ehv030) } & TATAATGCACGCCAACTTGC & \multirow[t]{2}{*}{98} & \multirow[t]{2}{*}{ This study } \\
\hline EhVpol_R & & GCAATTGCACCAAGTGGATA & & \\
\hline EhVpcna_R & PCNA (ehv440) & ATTCTCCGTCGACAATACGC & 157 & This study \\
\hline EhVhel_F & Helicase (ehv104) & GCCAACTGGTACAGGGAAAA & 184 & This study \\
\hline MCP_R2 & MCP (ehv085) & GTTCGCGCTCGAGTCGAT & 134 & Schroeder et al. (2002) \\
\hline
\end{tabular}





FIGURE 1 | Growth rates (A,C) and viral lysis rates (B,D) for the EhV86 Coccolithovirus in the presence of $(A, B) C d, C o, C u$, and $\mathrm{Zn}$ and $(C, D)$ at $\mathrm{Cu}$ concentrations between 125 and $1000 \mathrm{nM}$ in the presence (black bars) and absence (gray bars) of $5 \mu \mathrm{M}$ EDTA.

the controls in each experiment for the post infection period and reflected results observed in preliminary experiments (Figure 1). Cellular GSH concentrations (Figure 3) were $66 \pm 10 \mathrm{amol} \mathrm{cell}^{-1}$ on day 0 for the $\mathrm{Cu}$ experiment and $120 \pm 20 \mathrm{amol} \mathrm{cell}^{-1}$ for the $\mathrm{Cd}$ experiment and are similar to those reported previously for E. huxleyi and marine phytoplankton (Ahner et al., 1995; Kawakami et al., 2006c). Cellular GSH content increased in the infected treatments (Figure 3). For the $\mathrm{Cu}$ experiment, $\mathrm{GSH}$ remained similar in both $\mathrm{Cu}$ and $+\mathrm{Cu}+$ Virus treatments, while in the Cd experiment, cellular GSH levels in the Cd treatment were similar to the control, while levels increased in the $+\mathrm{Cd}+$ Virus treatment (Figure 3 ). A previous study on infected E. huxleyi cells indicated an increased intracellular occurrence of ROS and oxidative stress (Evans et al., 2006). The increase in GSH in virus infected cells in this study is consistent with a response to increased oxidative stress on viral infection. Glutathione content in the $+\mathrm{Cd}+$ Virus treatment increased to an average of $216 \pm 11 \mathrm{amol} \mathrm{cell}^{-1}$ between days 4 and 6 after infection and was closer to that of the virus treatment $\left(316 \pm 27 \mathrm{amolcell}^{-1}\right)$ than the $\mathrm{Cd}$ treatment $\left(46 \pm 29 \mathrm{amol} \mathrm{cell}^{-1}\right)$ and control $\left(50 \pm 11 \mathrm{amol} \mathrm{cell}^{-1}\right)$. In contrast the cellular GSH content of the $+\mathrm{Cu}+$ Virus treatment was $55 \pm 16 \mathrm{amolcell}^{-1}$, similar to that of the $\mathrm{Cu}$ treatment $\left(55 \pm 19\right.$ amol cell $\left.^{-1}\right)$, but less than GSH in the virus treatment $\left(124 \pm 85\right.$ amol cell $\left.^{-1}\right)$, although there was a marked increase in GSH variability in this treatment and the difference between the virus treatment and the control was not as marked as for the Cd experiment (Figure 3). These results indicate that the ROS event associated with viral infection is reduced by $\mathrm{Cu}$.



D

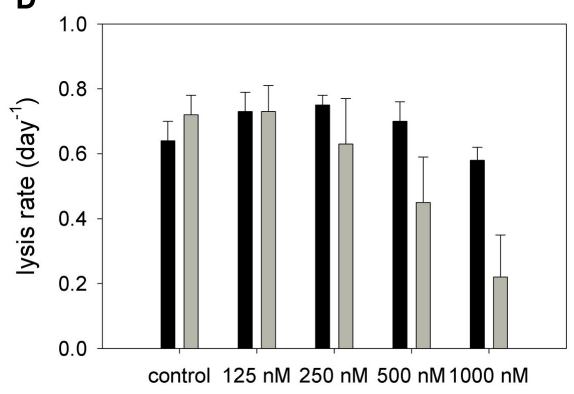

Errors were calculated from the square root of the sum of squares of the errors in the slopes obtained from linear regression of In(cells) against time for the period over which lysis occurred in the +virus treatment.

Phytochelatin concentrations increased after addition of both $\mathrm{Cu}$ and $\mathrm{Cd}$ (Figure 4). Virus treatments showed only a slight increase in PC concentrations, although the small E. huxleyi biovolume in these treatments resulted in very low absolute PC concentrations and the calculated errors are likely underestimated. Cellular phytochelatin concentrations were higher in the $\mathrm{Cd}$ and $+\mathrm{Cd}+$ Virus treatments than in the $\mathrm{Cu}$ or $+\mathrm{Cu}+$ Virus treatments. Thus in contrast to the cellular GSH content, PC concentrations were observed to vary with metal treatment and not with infection of E. huxleyi by EhV86.

\section{EXPRESSION OF VIRUS-RELATED RNA}

In order to confirm the presence of EhV86 within $\mathrm{Cu}$ and $\mathrm{Cd}$ exposed E. huxleyi cells and to determine whether EhV86 was transcriptionally active when exposed to elevated levels of $\mathrm{Cu}$ and Cd, RT-PCR on four EhV86 encoded genes - DNA dependent DNA pol - ehv030, PCNA protein - ehv440, Helicase - ehv104 and MCP - ehv085 - was carried out in duplicate before and after treatment (Tables 2 and 3). Particulate material from $\mathrm{Cu}$ and $\mathrm{Cd}$ experiments in the absence of virus were also analyzed and viral RNA was not detected in any treatment not infected with the virus (Tables 2 and $\mathbf{3}$ ). Genomic studies have previously revealed that all four genes are required for successful infection (Wilson et al., 2005; Allen et al., 2006). DNA pol and helicase are required for DNA synthesis and therefore virus replication. The MCP is required for virion assembly and PCNA is known to be involved in several metabolic pathways, including Okazaki fragment processing, DNA repair, translesion DNA synthesis, DNA methylation, chromatin remodeling, and cell cycle regulation. PCNA in mammalian cells 


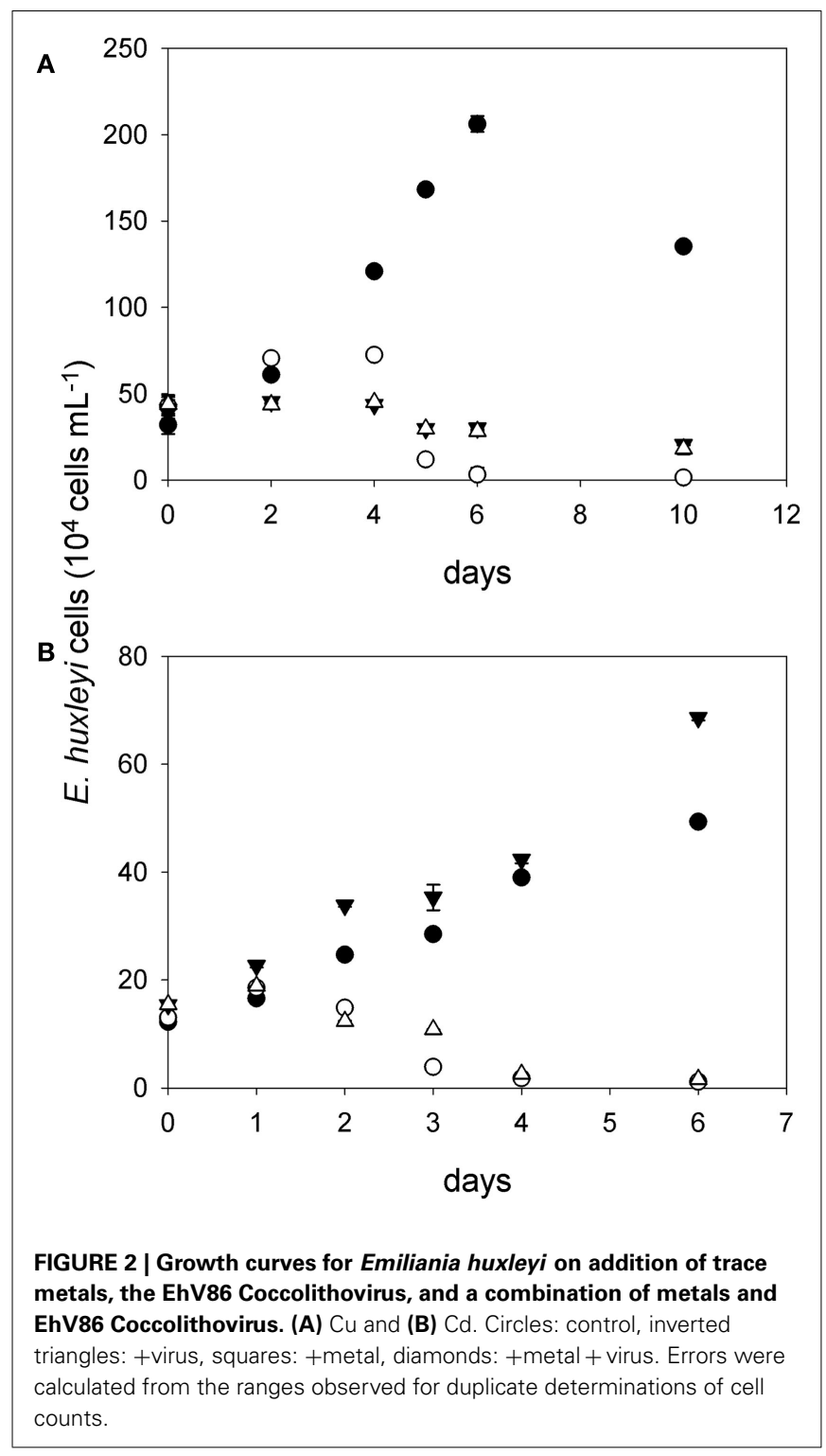

appears to play a key role in controlling several reactions through the coordination and organization of different partner proteins (Maga and Hubscher, 2003). DNA pol, helicase, and PCNA genes have been found to be expressed at around $2 \mathrm{~h}$ post infection, while MCP was only first detected $4 \mathrm{~h}$ post infection (Allen et al., 2006). We found that Cd had no observable effect on the transcription of all four genes (Table 3), consistent with observations of virus synthesis and culture lysis (Figures 3 and 4). However, in the presence of $\mathrm{Cu}$, only PCNA, and MCP genes were expressed. These results show that $\mathrm{Cu}$ did not therefore prevent virus entry into E. huxleyi cells. However, viral replication within E. huxleyi appears to have been reduced by $\mathrm{Cu}$ via an unknown mechanism of transcriptional control.

\section{DISCUSSION}

Our experiments indicated that metals have a direct effect on virus production and consequently infection success in the $E$.

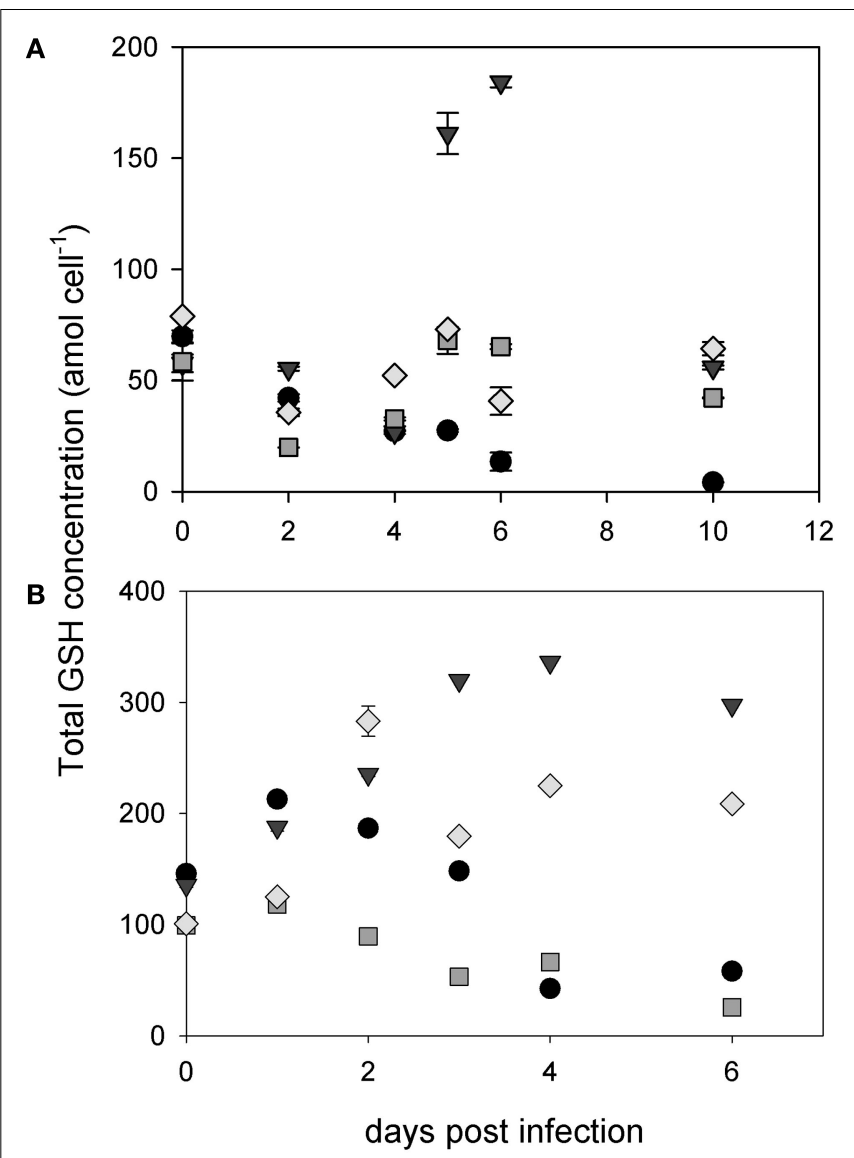

FIGURE 3 | Particulate glutathione (GSH) concentration (amol cell-1) in (A) Cu and (B) Cd treatments. Circles: control, inverted triangles: +virus, squares: +metal, diamonds: +metal +virus.

huxleyi - EhV86 system. Furthermore it appears that the effect is stronger for $\mathrm{Cu}$ than for $\mathrm{Cd}, \mathrm{Zn}$, and $\mathrm{Co}$ so that $\mathrm{Cu}$ caused a reduction in lytic infection in short term exposure experiments at high concentrations of total $\mathrm{Cu}$ ( $>$ approximately $500 \mathrm{nM})$. Although these concentrations are higher than commonly observed in the marine environment, such high concentrations have been recorded in contaminated estuarine systems (Braungardt et al., 2007). Furthermore, these experiments represented an acute exposure to high concentrations of metal. Further investigations are thus required in order to assess effects of long-term metal exposure.

The mechanism of the interaction between $\mathrm{Cu}$ and the E. huxleyi - EhV86 system is currently unknown. Our observations are summarized in Figure 5. Our data show that EhV86 did not have an impact on the production of PCs in E. huxleyi and thus was unlikely to have affected the toxicity of $\mathrm{Cu}$ to the host. The primary effect of $\mathrm{Cu}$ on the lytic cycle of EhV86 thus appears to result from greater sensitivity of the virus to $\mathrm{Cu}$ toxicity relative to the host. Viruses require metals for the functioning of their DNA and RNA replication enzymes, so it has been previously suggested that viral inactivation by $\mathrm{Cu}$ involves cleavage or damage of viral DNA or RNA (Sagripanti et al., 1997). Recent studies have linked 


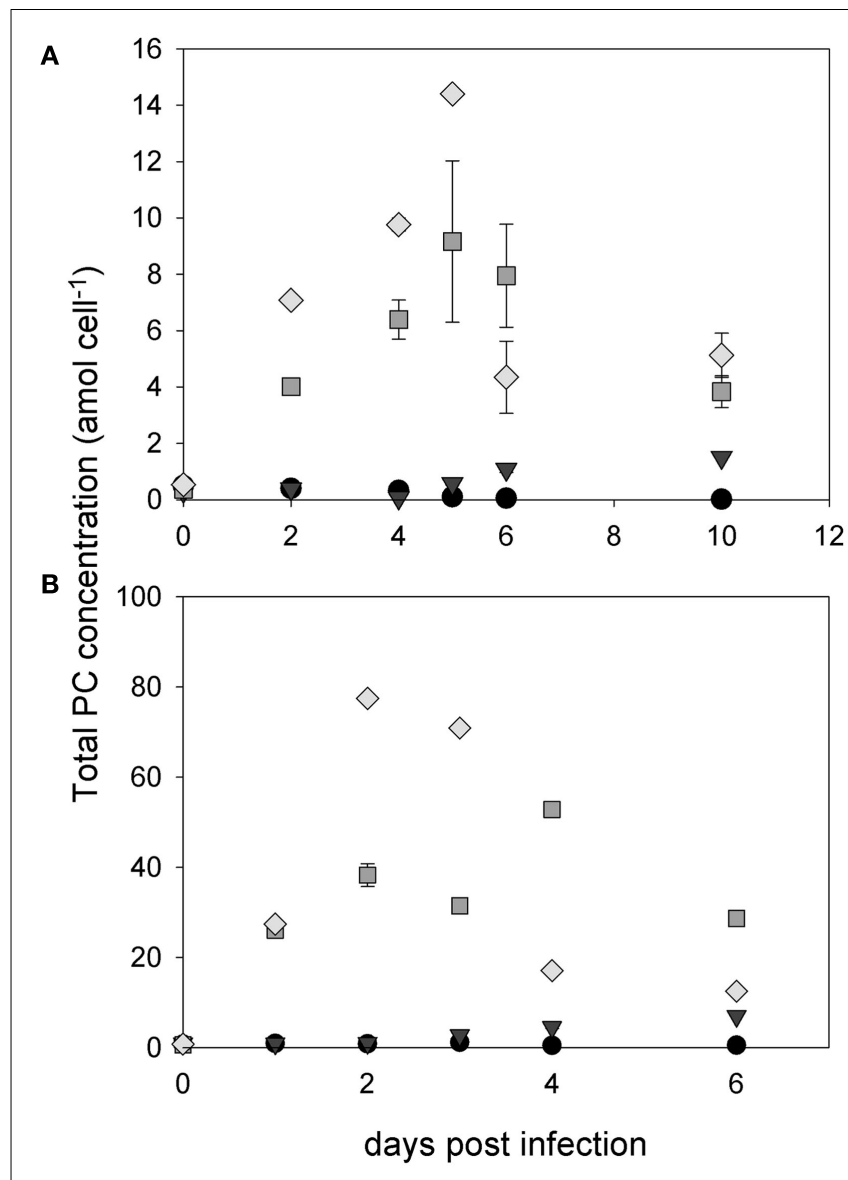

FIGURE 4 | Particulate phytochelatin (PC) concentration (amol cell ${ }^{-1}$ ) in (A) Cu and (B) Cd treatments. Circles: control, inverted triangles: +virus, squares: +metal, diamonds: +metal +virus.

Table 2 | RT-PCR results for Cu exposure experiments.

\begin{tabular}{|c|c|c|c|c|}
\hline & \multicolumn{4}{|c|}{ EhV86 genes } \\
\hline & DNA pol & Helicase & PCNA & MCP \\
\hline Control day 5 & - & - & - & - \\
\hline Control day 7 & - & - & - & - \\
\hline Cu day 5 & - & - & - & - \\
\hline Cu day 7 & - & - & - & - \\
\hline EhV86 day 7 (v2*) & + & + & + & + \\
\hline EhV86 day 10 (v5*) & + & + & + & + \\
\hline $\mathrm{Cu}+$ EhV86 day $5\left(\mathrm{vO}^{*}\right)$ & - & - & - & - \\
\hline $\mathrm{Cu}+$ EhV86 day $7\left(\mathrm{v} 2^{*}\right)$ & - & - & + & + \\
\hline $\mathrm{NTC}^{\wedge}$ & - & - & - & - \\
\hline
\end{tabular}

${ }^{*}$ Days post EhV86 addition; ^ no template control.

$\mathrm{Cu}$ exposure to a complete decline in virus particles confirming antiviral properties of $\mathrm{Cu}$-based agents and surfaces against major opportunistic pathogens (Noyce et al., 2006a,b, 2007; Huang et al., 2008; Weaver et al., 2008). However, in our study, virus particles were not observed to decline completely in the presence of $\mathrm{Cu}$,
Table 3 | RT-PCR results for Cd exposure experiments.

\begin{tabular}{|c|c|c|c|c|}
\hline & \multicolumn{4}{|c|}{ EhV86 genes } \\
\hline & DNA pol & Helicase & PCNA & MCP \\
\hline EhV86 day 4 (vo*) & - & - & - & - \\
\hline EhV86 day $5\left(\mathrm{v} 1^{*}\right)$ & + & + & + & + \\
\hline EhV86 day 6 (v2*) & + & + & + & + \\
\hline EhV86 day 7 (v3*) & + & + & + & + \\
\hline EhV86 day $8\left(\mathrm{v} 4^{*}\right)$ & + & + & + & + \\
\hline Cd day 4 & - & - & - & - \\
\hline Cd day 5 & - & - & - & - \\
\hline Cd day 6 & - & - & - & - \\
\hline Cd day 7 & - & - & - & - \\
\hline Cd day 8 & - & - & - & - \\
\hline $\mathrm{Cd}+$ EhV86 day $4\left(\mathrm{vO}^{*}\right)$ & - & - & - & - \\
\hline $\mathrm{Cd}+$ EhV86 day $5\left(\mathrm{v} 1^{*}\right)$ & + & + & + & + \\
\hline $\mathrm{Cd}+$ EhV86 day $6\left(\mathrm{v} 2^{*}\right)$ & + & + & + & + \\
\hline $\mathrm{Cd}+$ EhV86 day $7\left(\mathrm{v}^{*}\right)$ & + & + & + & + \\
\hline $\mathrm{Cd}+$ EhV86 day $8\left(\mathrm{v} 4^{*}\right)$ & + & + & + & + \\
\hline $\mathrm{NTC}^{\wedge}$ & - & - & - & - \\
\hline
\end{tabular}

${ }^{*}$ Days post EhV86 addition; ${ }^{\wedge}$ no template control.

and furthermore, RNA transcripts for both PCNA and MCP were detected. The lack of DNA pol and helicase transcripts indicates that a specific mechanism of $\mathrm{Cu}$ inhibition was at play. DNA pol and helicase are both associated with DNA synthesis and replication, hence it appears that $\mathrm{Cu}$ disrupted virus replication within the host cell, although further work is needed to identify whether this is a result of exposure of the virus to elevated free $\mathrm{Cu}$ within the host cell or in the media prior to entry into the host. However since neither MCP or PCNA are affected, we hypothesize that virion assembly, DNA repair, and other cellular functions associated with PCNA were not regulated at the transcriptional level by $\mathrm{Cu}$. Thus, despite being involved in DNA replication and repair, viral PCNA was not regulated in the same way as dedicated DNA replicative enzymes, DNA pol, and helicase. It is interesting to note that both DNA pol and helicase encode for magnesium containing proteins, while PCNA and MCP do not, although whether this factor might influence the inhibition of transcription of the associated RNA is unclear. Intracellular free $\mathrm{Cu}$ concentrations in eukaryotes and prokaryotes are generally thought to be tightly controlled, with $\mathrm{Cu}$ being buffered within the cell by thiols and chaperoned into $\mathrm{Cu}$ containing enzymes (Robinson and Winge, 2010; Rae et al., 1999). The intravirion behavior of metals however is less well known, but our studies indicate that EhV86 may be less able to regulate $\mathrm{Cu}$. Previous studies on the effects of $\mathrm{Cu}$ on the transcriptional control of genes have indicated regulation of $\mathrm{Cu}$ is achieved by modulating the transcription of genes encoding proteins directly involved in $\mathrm{Cu}$ binding. Transcription of the Ctr1/3 and Fre1 genes are regulated by the DNA-binding protein Mac1 (Yamaguchi-Iwai et al., 1997). During Cu starvation, Mac1 binds to DNA initiating transcription. However, in Cu replete conditions, Jensen and Winge (1998) demonstrated that $\mathrm{Cu}$ ions bind to the protein, initiating a conformational change which inhibits transcription. Transcriptional regulation of these $\mathrm{Cu}$ uptake genes 


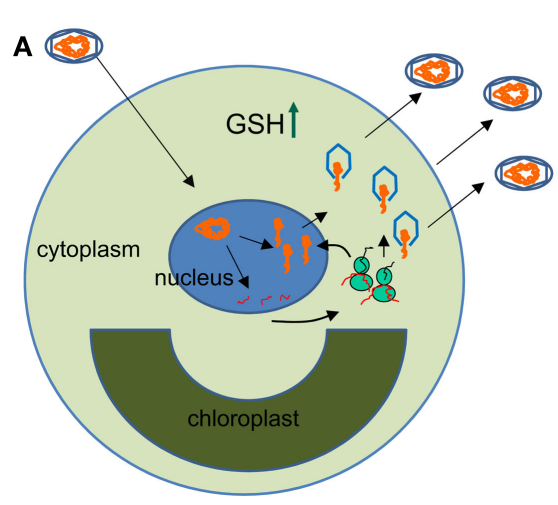

FIGURE 5 | Schematic of the interactive effect of $\mathrm{Cu}$ on the infection cycle of EhV86. (A) Simplified schematic of the normal infection cycle of EhV86 (after Mackinder et al., 2009). The virion particle (blue hexagon) enters the cell and targets the nucleus where it releases the viral genome. Viral genes are transcribed (red) first by host RNA polymerase in the nucleus and then by viral RNA polymerase in the cytoplasm. Virus DNA replication (orange) also takes place in the nucleus, while the capsid is assembled in the cytoplasm and released via a budding mechanism.
B



Cellular glutathione (GSH) increases (green arrow) as a result of reactive oxygen species generation, which occurs during capsid assembly. (B) Copper down-regulates (green arrow) the infection cycle prior to capsid assembly via transcriptional control of specific viral RNA. Cellular phytochelatin concentrations (PCs) increase in response to elevated copper concentrations, but GSH concentrations are similar to those in uninfected cells as capsid assembly is highly reduced. The ultimate result is a reduction in virus production.

has therefore been linked directly to cellular $\mathrm{Cu}$ concentrations (Graden and Winge, 1997).

The second observed effect of $\mathrm{Cu}$ in our study was on particulate GSH concentrations, which were similar to controls in infected E. huxleyi cells in the presence of $\mathrm{Cu}$, but increased in E. huxleyi cells undergoing lysis, even when the concentrations of phytochelatins were higher (Figure 3). These results indicate that $\mathrm{GSH}$, known to mitigate against ROS, is produced by the host when the virus replicates probably as a result of the viral induction of the hosts ceramide and apoptosis pathways (Schwarz, 1996; Stohs et al., 2001; Wilson et al., 2005; Bidle et al., 2007; Vardi et al., 2009). Moreover, GSH can also directly interfere with virus replication, mainly at the late stages of virion assembly (Palamara et al., 1995). Therefore, in our $\mathrm{Cu}$ exposed virus treatments, GSH production decreased when compared to virus treatments because the virus was unable to complete its replication and infection cycle and GSH was thus not induced to the same extent in the host.

To the authors knowledge, this is the first report of an interaction occurring between metals, virus, and host in a marine system. We have identified a specific interaction between $\mathrm{Cu}, E$. huxleyi and its virus EhV86, however, further work is necessary

\section{REFERENCES}

Ahner, B. A., Kong, S., and Morel, F. M. M. (1995). Phytochelatin production in marine algae. 1 . An interspecies comparison. Limnol. Oceanogr. 40, 649-657.

Ahner, B. A., and Morel, F. M. M. (1995). Phytochelatin production in marine algae 2 . Induction by various metals. Limnol. Oceanogr. 40, 658-665.

Allen, M. J., Forster, T., Schroeder, D. C., Hall, M., Roy, D., Ghazal, P., and Wilson, W. H. (2006). Locus-specific gene expression pattern suggests a unique propagation strategy for a giant algal virus. J. Virol. 80, 7699-7705.

Aruoma, O. I., Halliwell, B., Gajewski, E., and Dizdaroglu, M. (1991). Copper ion dependent damage to the bases in DNA in the presence of hydrogen peroxide. Biochem. J. 273, 601-604.

Bergh, O., Borsheim, K. Y., Bratbak, G., and Heldal, M. (1989). High abundance of viruses found in aquatic environments. Nature 340, 467-468.

Bidle, K. D., and Falkowski, P. G. (2004). Cell death in planktonic, photo-

in order to understand the mechanism involved in this interaction. Concentrations of $\mathrm{Cu}$ required to initiate the inhibitory effect on virus replication and virion synthesis were found to be comparable to those observed in highly $\mathrm{Cu}$ contaminated estuaries (Braungardt et al., 2007). However the study focused on short term acute exposure to $\mathrm{Cu}$. It is currently unknown if any effects would be observed on long-term exposure to lower concentrations. However, the increased use of $\mathrm{Cu}$-based antifouling paints in marine systems (Schiff et al., 2004; Singh and Turner, 2009a,b) and the importance of phytoplankton communities in underpinning global climate control (Richardson and Schoeman, 2004; Bouvy et al., 2011) highlights the need to understand such mechanisms. The immediate medical benefit that can be had by fully characterizing the Cu inhibitory effort on the E. huxleyi - EhV86 model system for developing antiviral drugs and protocols against animal virus infections should also be considered.

\section{ACKNOWLEDGMENTS}

Gledhill was supported by UK - NERC Advanced Fellowship (NE/E013546/1) and Devez was supported by a Marie Curie Intra-European Fellowship (FP6-023215-QWSTRESS).

synthetic microorganisms. Nat. Rev. Microbiol. 2, 643-655.

Bidle, K. D., Haramaty, L., Barcelos, E., Ramos, J., and Falkowski, P. (2007). Viral activation and recruitment of metacaspases in the unicellular coccolithophore, Emiliania huxleyi. Proc. Natl. Acad. Sci. U.S.A. 104, 6049-6054.

Bidle, K. D., and Vardi, A. (2011). A chemical arms race at sea mediates algal host-virus interactions. Curr. Opin. Microbiol. 14, 449-457.

Bouvy, M., Bettarel, Y., Bouvier, C., Domaizon, I., Jacquet, S., Le Floc'h,
E., Montanie, H., Mostajir, B. Sime-Ngando, T., Torreton, J. P., Vidussi, F., and Bouvier, T. (2011). Trophic interactions between viruses, bacteria and nanoflagellates under various nutrient conditions and simulated climate change. Environ. Microbiol. 13, 1842-1857.

Brand, L. E., Sunda, W. G., and Guillard, R. R. L. (1986). Reduction of marine phytoplankton reproduction rates by copper and cadmium. J. Exp. Mar. Biol. Ecol. 96, 225-250. 
Braungardt, C. B., Achterberg, E. P., Gledhill, M., Nimmo, M., ElbazPoulichet, F., Cruzado, A., and Velasquez, Z. (2007). Chemical speciation of dissolved $\mathrm{Cu}, \mathrm{Ni}$, and $\mathrm{Co}$ in a contaminated estuary in southwest Spain and its influence on plankton communities. Environ. Sci. Technol. 41, 4214-4220.

Curtain, C. C., Ali, F., Volitakis, I., Cherny, R. A., Norton, R. S., Beyreuther, K., Barrow, C. J., Masters, C. L., Bush, A. I., and Barnham, K. J. (2001). Alzheimer's disease amyloid-beta binds copper and zinc to generate an allosterically ordered membranepenetrating structure containing superoxide dismutase-like subunits. J. Biol. Chem. 276, 20466-20473.

Debelius, B., Forja, J. M., Delvalls, A., and Lubian, L. M. (2009). Toxicity and bioaccumulation of copper and lead in five marine microalgae. Ecotoxicol. Environ. Saf. 72, 1503-1513.

Devez, A., Achterberg, E. P., and Gledhill, M. (2009). "Metal ion-binding properties of phytochelatins and related ligands," in Metal Ions in Life Sciences, eds A. Sigel, H. Sigel, and K. O. Sigel (Cambridge: Royal Society of Chemistry), 441-481.

Dupont, C. L., and Ahner, B. A. (2005). Effects of copper, cadmium, and zinc on the production and exudation of thiols by Emiliania huxleyi. Limnol. Oceanogr. 50, 508-515.

Evans, C., Malin, G., Mills, G. P., and Wilson, W. H. (2006). Viral infection of Emiliania huxleyi (Prymnesiophyceae) leads to elevated production of reactive oxygen species. J. Phycol. 42, 1040-1047.

Gledhill, M., Nimmo, M., Hill, S. J., and Brown, M. T. (1997). The toxicity of copper(II) species to marine algae, with particular reference to macroalgae. J. Phycol. 33, 2-11.

Gobler, C. J., Hutchins, D. A., Fisher, N. S., Cosper, E. M., and SanudoWilhelmy, S. (1997). Release and bioavailability of $\mathrm{C}, \mathrm{N}, \mathrm{P}, \mathrm{Se}$ and Fe following viral lysis of a marine chrysophyte. Limnol. Oceanogr. 42, 1492-1504.

Graden, J. A., and Winge, D. R. (1997). Copper-mediated repression of the activation domain in the yeast Maclp transcription factor. Proc. Natl. Acad. Sci. U.S.A. 94, 5550-5555.

Han, G., Gable, K., Yan, L., Allen, M. J., Wilson, W. H., Moitra, P., Harmon, J. M., and Dunn, T. M. (2006). Expression of a novel marine viral single-chain serine palmitoyltransferase and construction of yeast and mammalian single-chain chimera. J. Biol. Chem. 281, 39935-39942.

Heller, M. I., and Croot, P. L. (2010). Superoxide decay kinetics in the Southern Ocean. Environ. Sci. Technol. 44, 191-196.

Heller, M. I., and Croot, P. L. (2011). Superoxide decay as a probe for speciation changes during dust dissolution in Tropical Atlantic surface waters near Cape Verde. Mar. Chem. 126, 37-55.

Horie, M., Ogawa, H., Yoshida, Y., Yamada, K., Hara, A., Ozawa, K., Matsuda, S., Mizota, C., Tani, M., Yamamoto, Y., Yamada, M., Nakamura, K., and Imai, K. (2008). Inactivation and morphological changes of avian influenza virus by copper ions. Arch. Virol. 153, 1467-1472.

Huang, H.-I., Shih, H.-Y., Lee, C.M., Yang, T. C., Lay, J.-J., and Lin, Y. E. (2008). In vitro efficacy of copper and silver ions in eradicating Pseudomonas aeruginosa, Stenotrophomonas maltophilia and Acinetobacter baumannii: implications for on-site disinfection for hospital infection control. Water Res. 42, 73-80.

Huang, Y. H., Shih, C. M., Huang, C. J., Lin, C. M., Chou, C. M., Tsai, M. L., Liu, T. P., Chiu, J. F., and Chen, C. T. (2006). Effects of cadmium on structure and enzymatic activity of $\mathrm{Cu}, \mathrm{Zn}-\mathrm{SOD}$ and oxidative status in neural cells. J. Cell. Biochem. 98, 577-589.

Hussain, T., Shukla, G. S., and Chandra, S. V. (1987). Effects of cadmium on superoxide-dismutase and lipid peroxidation in liver and kidney of growing rats - in vivo and in vitro studies. Pharmacol. Toxicol. 60, 355-358.

Jensen, L. T., and Winge, D. R. (1998). Identification of a copper-induced intramolecular interaction in the transcription factor $\mathrm{Macl}$ from $\mathrm{Sac}$ charomyces cerevisiae. EMBO J. 17, 5400-5408.

Karlstrom, A. R., and Levine, R. L. (1991a). Copper inhibits the HIV-1 protease by both oxygen-dependent and oxygen independent mechanisms. FASEB J. 5, A452-A452.

Karlstrom, A. R., and Levine, R. L. (1991b). Copper inhibits the protease from human immunodeficiency virus-1 by both cysteinedependent and cysteine independent mechanisms. Proc. Natl. Acad. Sci. U.S.A. 88, 5552-5556.

Kawakami, S. K., Gledhill, M., and Achterberg, E. P. (2006a). Determination of phytochelatins and glutathione in phytoplankton from natural waters using HPLC with fluorescence detection. Trends Analyt. Chem. 25, 133-142.

Kawakami, S. K., Gledhill, M., and Achterberg, E. P. (2006b). Effects of metal combinations on the production of phytochelatins and glutathione by the marine diatom Phaeodactylum tricornutum. Biometals 19, 51-60.

Kawakami, S. K., Gledhill, M., and Achterberg, E. P. (2006c). Production of phytochelatins and glutathione by marine phytoplankton in response to metal stress. J. Phycol. 42, 975-989.

Lane, T. W., Saito, M. A., George, G. N., Pickering, I. J., Prince, R. C., and Morel, F. M. M. (2005). A cadmium enzyme from a marine diatom. Nature 435, 42-42.

Le Faucheur, S. V., Behra, R., and Sigg, L. (2005). Thiol and metal contents in periphyton exposed to elevated copper and zinc concentrations: a field and microcosm study. Environ. Sci. Technol. 39, 8099-8107.

Leal, M. F. C., Vasconcelos, M. T. S. D., and van den Berg, C. M. G. (1999). Copper-induced release of complexing ligands similar to thiols by Emiliania huxleyi in seawater cultures. Limnol. Oceanogr. 44, 1750-1762.

Lee, J., Ahner, B. A., and Morel, F. M. M. (1996). Export of cadmium and phytochelatin by the marine diatom Thalassiosira weissflogii. Environ. Sci. Technol. 30, 1814-1821.

Levinson, W., Faras, A., Woodson, B., Jackson, J., and Bishop, J. M. (1973). Inhibition of RNA-dependent DNA polymerase of Rous sarcoma virus by thiosemicarbazones and several cations. Proc. Natl. Acad. Sci. U.S.A. 70, 164-168.

Levy, J. L., Angel, B. M., Stauber, J. L., Poon, W. L., Simpson, S. L., Cheng, S. H., and Jolley, D. F. (2008). Uptake and internalisation of copper by three marine microalgae: comparison of copper-sensitive and coppertolerant species. Aquat. Toxicol. 89, 82-93.

Levy, J. L., Stauber, J. L., and Jolley, D. F. (2007). Sensitivity of marine microalgae to copper: the effect of biotic factors on copper adsorption and toxicity. Sci. Total Environ. 387, 141-154.

Lovell, M. A., Robertson, J. D., Teesdale, W. J., Campbell, J. L., and Markesbery, W. R. (1998). Copper, iron and zinc in Alzheimer's disease senile plaques. J. Neurol. Sci. 158, 47-52.

Mackinder, L. C. M., Worthy, C. A., Biggi, G., Hall, M., Ryan, K. P., Varsani, A., Harper, G. M., Wilson, W. H., Brownlee, C., and Schroeder,
D. C. (2009). A unicellular algal virus, Emiliania huxleyi virus 86 exploits an animal-like infection strategy. J. Gen. Virol. 90, 2306-2316.

Maga, G., and Hubscher, U. (2003). Proliferating cell nuclear antigen (PCNA): a dancer with many partners. J. Cell. Sci. 116, 3051-3060.

Mendoza-Cozatl, D., Loza-Tavera, H., Hernandez-Navarro, A., and Moreno-Sanchez, R. (2005). Sulfur assimilation and glutathione metabolism under cadmium stress in yeast, protists and plants. FEMS Microbiol. Rev. 29, 653-671.

Mioni, C., Poorvin, L., and Wilhelm, S. W. (2005). Virus and siderophore-mediated transfer of available $\mathrm{Fe}$ between heterotrophic bacteria: characterisation using an iron specific reporter. Aquat. Microb. Ecol. 41, 233-245.

Morel, F. M. M., and Price, N. M. (2003). The biogeochemical cycles of trace metals in the oceans. Science 300 , 944-947.

Morel, N. M. L., Rueter, J. G., and Morel, F. M. M. (1978). Copper toxicity to Skeletonema costatum (Bacillariophyceae). J. Phycol. 14, 43-48.

Morelli, E., and Fantozzi, L. (2008). Phytochelatins in the diatom Phaeodactylum tricornutum Bohlin: an evaluation of their use as biomarkers of metal exposure in marine waters. Bull. Environ. Contam. Toxicol. 81, 236-241.

Morelli, E., and Scarano, G. (2001). Synthesis and stability of phytochelatins induced by cadmium and lead in the marine diatom Phaeodactylum tricornutum. Mar. Environ. Res. 52, 383-395.

Noyce, J. O., Michels, H., and Keevil, C. W. (2006a). Potential use of copper surfaces to reduce survival of epidemic meticillin-resistant Staphylococcus aureus in the healthcare environment. J. Hosp. Infect. 63, 289-297.

Noyce, J. O., Michels, H., and Keevil, C. W. (2006b). Use of copper cast alloys to control Escherichia coli O157 cross-contamination during food processing. Appl. Environ. Microbiol. 72, 4239-4244.

Noyce, J. O., Michels, H., and Keevil, C. W. (2007). Inactivation of influenza A virus on copper versus stainless steel surfaces. Appl. Environ. Microbiol. 73, 2748-2750.

Pagarete, A., Allen, M. J., Wilson, W. H., Kimmance, S. A., and De Vargas, C. (2009). Host-virus shift of the sphingolipid pathway along an Emiliania huxleyi bloom: survival of the fattest. Environ. Microbiol. 11, 2840-2848. 
Palamara, A. T., Perno, C. F., Ciriolo, M. R., Dini, L., Balestra, E., Dagostini, C., Difrancesco, P., Favalli, C., Rotilio, G., and Garaci, E. (1995). Evidence for antiviral activity of glutathione - in vitro inhibition of $\mathrm{Her}$ pes simplex virus type-1 replication. Antiviral Res. 27, 237-253.

Pawlik-Skowronska, B., Pirszel, J., and Brown, M. T. (2007). Concentrations of phytochelatins and glutathione found in natural assemblages of seaweeds depend on species and metal concentrations of the habitat. Aquat. Toxicol. 83, 190-199.

Permyakov, E. (2009). Metalloproteomics. Hoboken, NJ: John Wiley.

Price, N. M., and Morel, F. M. M. (1990). Cadmium and cobalt substitution for zinc in a marine diatom. Nature 344, 658-660.

Rae, T. D., Schmidt, P. J., Pufahl, R. A., Culotta, V. C., and O'Halloran, T. V. (1999). Undetectable intracellular free copper: the requirement of a copper chaperone for superoxide dismutase. Science 284, 805-808.

Richardson, A. J., and Schoeman, D. S. (2004). Climate impact on plankton ecosystems in the Northeast Atlantic. Science 305, 1609-1612.

Robinson, N. J., and Winge, D. R. (2010). "Copper metallochaperones," in Annual Review of Biochemistry, Vol. 79, eds R. D. Kornberg, C. R. H. Raetz, J. E. Rothman, and J. W. Thorner (Palo Alto: Annual Reviews), 537-562.

Sagripanti, J. L., and Kraemer, K. H. (1989). Site specific oxidative DNA damage at polyguanosines produced by copper plus hydrogen peroxide. J. Biol. Chem. 264, 1729-1734.

Sagripanti, J. L., Routson, L. B., Bonifacino, A. C., and Lytle, C. D. (1997). Mechanism of coppermediated inactivation of Herpes simplex virus. Antimicrob. Agents Chemother. 41, 812-817.

Sandaa, R. A. (2008). Burden or benefit? Virus-host interactions in the marine environment. Res. Microbiol. 159, 374-381.
Schafer, F. Q., and Buettner, G. R. (2001). Redox environment of the cell as viewed through the redox state of the glutathione disulfide/glutathione couple. Free Radic. Biol. Med. 30, 1191-1212.

Scheidegger, C., Behra, R., and Sigg, L. (2011). Phytochelatin formation kinetics and toxic effects in the freshwater alga Chlamydomonas reinhardtii upon short- and long-term exposure to lead(II). Aquat. Toxicol. 101, 423-429.

Schiff, K., Diehl, D., and Valkirs, A. (2004). Copper emissions from antifouling paint on recreational vessels. Mar. Pollut. Bull. 48, 371-377.

Schroeder, D. C., Oke, J., Malin, G., and Wilson, W. H. (2002). Coccolithovirus (Phycodnaviridae): characterisation of a new large dsDNA algal virus that infects Emiliania huxleyi. Arch. Virol. 147, 1685-1698.

Schwarz, K. B. (1996). Oxidative stress during viral infection: a review. Free Radic. Biol. Med. 21, 641-649.

Singh, N., and Turner, A. (2009a). Leaching of copper and zinc from spent antifouling paint particles. Environ. Pollut. 157, 371-376.

Singh, N., and Turner, A. (2009b). Trace metals in antifouling paint particles and their heterogeneous contamination of coastal sediments. Mar. Pollut. Bull. 58, 559-564.

Sorensen, G., Baker, A. C., Hall, M. J., Munn, C. B., and Schroeder, D. C. (2009). Novel virus dynamics in an Emiliania huxleyi bloom. J. Plankton Res. 31, 787-791.

Stohs, S. J., Bagchi, D., Hassoun, E., and Bagchi, M. (2001). Oxidative mechanisms in the toxicity of chromium and cadmium ions. J. Environ. Pathol. Toxicol. Oncol. 20, 77-88.

Sunda, W. G. (1988). Trace metal interactions with marine phytoplankton. Biol. Oceanogr. 6, 411-442.

Sunda, W. G., and Guillard, R. R. L. (1976). The relationship between cupric ion activity and toxicity of copper to phytoplankton. J. Mar. Res. 34, 511-529.

Suttle, C. A. (2007). Marine viruses major players in the global ecosystem. Nat. Rev. Microbiol. 5, 801-812.

Vardi, A., Van Mooy, B. A. S., Fredricks, H. F., Popendorf, K. J., Ossolinski, J. E., Haramaty, L., and Bidle, K. D. (2009). Viral glycosphingolipids induce lytic infection and cell death in marine phytoplankton. Science 326, 861-865.

Vasconcelos, M., and Leal, M. F. C. (2001). Adsorption and uptake of $\mathrm{Cu}$ by Emiliania huxleyi in natural seawater. Environ. Sci. Technol. 35, 508-515.

Vasconcelos, M., Leal, M. F. C., and van den Berg, C. M. G. (2002). Influence of the nature of the exudates released by different marine algae on the growth, trace metal uptake, and exudation of Emiliania huxleyi in natural seawater. Mar. Chem. 77, 187-210.

Voelker, B. M., Sedlak, D. L., and Zafiriou, O. C. (2000). Chemistry of superoxide radical in seawater: reactions with organic $\mathrm{Cu}$ complexes. Environ. Sci. Technol.34, 1036-1042.

Weaver, L., Michels, H. T., and Keevil, C. W. (2008). Survival of Clostridium difficile on copper and steel: futuristic options for hospital hygiene. J. Hosp. Infect. 68, 145-151.

Weinbauer, M. G., Arrieta, J. M. Griebler, C., and Herndl, G. J. (2009). Enhanced viral production and infection of bacterioplankton during an iron-induced phytoplankton bloom in the Southern Ocean. Limnol. Oceanogr. 54, 774-784.

Wilhelm, S. W., and Suttle, C. A. (1999). Viruses and nutrient cycles in the sea - viruses play critical roles in the structure and function of aquatic food webs. Bioscience 49 , 781-788.

Wilson, W. H., Schroeder, D. C., Allen, M. J., Holden, M. T. G., Parkhill, J. Barrell, B. G., Churcher, C., Harnlin, N., Mungall, K., Norbertczak,
H., Quail, M. A., Price, C., Rabbinowitsch, E., Walker, D., Craigon, M., Roy, D., and Ghazal, P. (2005). Complete genome sequence and lytic phase transcription profile of a Coccolithovirus. Science 309, 1090-1092.

Wilson, W. H., Tarran, G. A., Schroeder, D., Cox, M., Oke, J., and Malin, G. (2002). Isolation of viruses responsible for the demise of an Emiliania huxleyi bloom in the English channel. J. Mar. Biolog. Assoc. U.K. 82, 369-377.

Yamaguchi-Iwai, Y., Serpe, M., Haile, D., Yang, W. M., Kosman, D. J., Klausner, R. D., and Dancis, A. (1997). Homeostatic regulation of copper uptake in yeast via direct binding of $\mathrm{MAC1}$ protein to upstream regulatory sequences of FRE1 and CTR1. J. Biol. Chem. 272, 17711-17718.

Conflict of Interest Statement: The authors declare that the research was conducted in the absence of any commercial or financial relationships that could be construed as a potential conflict of interest.

Received: 08 December 2011; paper pending published: 01 February 2012; accepted: 04 April 2012; published online: 23 April 2012.

Citation: Gledhill M, Devez A, Highfield A, Singleton $C$, Achterberg $E P$ and Schroeder D (2012) Effect of metals on the lytic cycle of the Coccolithovirus, EhV86. Front. Microbio. 3:155. doi: 10.3389/fmicb.2012.00155

This article was submitted to Frontiers in Microbiological Chemistry, a specialty of Frontiers in Microbiology.

Copyright (c) 2012 Gledhill, Devez, Highfield, Singleton, Achterberg and Schroeder. This is an open-access article distributed under the terms of the Creative Commons Attribution Non Commercial License, which permits noncommercial use, distribution, and reproduction in other forums, provided the original authors and source are credited. 